\title{
"MODERNO À MODA ANTIGA": DISCURSOS TERAPÊUTICOS, CONCEPÇÕES ROMÂNTICAS E PERFORMANCES DE GÊNERO NO MOVIMENTO EU ESCOLHI ESPERAR
}

\section{Luiza Terassi Hortelan ${ }^{I}$}

\begin{abstract}
Resumo: O Eu Escolhi Esperar é um movimento evangélico em defesa da abstinência sexual antes do casamento. $O$ objetivo deste artigo é refletir sobre como o amor vem sendo mobilizado nos discursos do movimento, que colocam a felicidade amorosa como a recompensa para quem "escolhe" e suporta a "espera". Ao mesmo tempo, se guardar sexualmente para o casamento torna-se uma questão não apenas de pecado, mas, sobretudo, de "saúde" e "inteligência emocional". Pretende-se demonstrar como os discursos evangélicos em torno dos relacionamentos afetivosexuais possuem ligaçôes com a cultura afetiva contemporânea, ainda que visem a produção de famílias heterossexuais, sólidas e indissolúveis, baseadas em papeis tradicionais de gênero. Assim, tais pedagogias, que elencam a abstinência como uma escolha, produzem, em articulaçáo de diferentes campos discursivos não-religiosos, códigos, convençôes e performances de gênero singulares, que atravessam as expectativas, buscas e trajetórias amorosas dos sujeitos.
\end{abstract}

Palavras-chave: Evangélicos; Amor; Gênero; Sexualidade.

Abstract: The Eu Escolhi Esperar (I Chose to Wait) is an evangelical movement focused in pre-marriage sexual abstinence's defense. The purpose of this article is to reflect on how love has been mobilized in the movement's discourses, which place love's happiness as the reward for those who "choose" and endure "the waiting". At the same time, saving oneself sexually for marriage becomes an issue not only of sin, but, mostly, of "health" and "emotional intelligence". It aims to demonstrate how evangelical discourses around affective-sexual relashionships are linked with the contemporary affective culture, even though their intention is to generate heterosexual, solid and indissoluble families, based on traditional gender roles. Thus, such pedagogies, which list abstinence as a choice, produce, in articulation with

1 Mestrado em andamento no Programa de Pós-Graduação em Antropologia Social Unicamp e Pagu - Núcleo de Estudos de Gênero. Contato: luviterassi@gmail.com

Debates do NER, Porto Alegre, ANo i9, N. 34, P. 25 I-277, Ago./Dez. 20 i 8 
different non-religious discoursive fields, singular codes, conventions and gender performances that cross the subjects' expectations, persuits and love trajectories.

Keywords: Evangelicals; Love; Gender; Sexuality.

\section{INTRODUÇÃO}

Idealizado por Nelson Júnior, um pastor de jovens da igreja capixaba Vitória em Cristo, o movimento Eu Escolhi Esperar surgiu em 2011 como uma campanha virtual pró-abstinência sexual, através de uma conta no Twitter. Nas palavras de Nelson, trata-se de uma campanha que visa "promover a pureza sexual e a saúde emocional". Devido a seu caráter interdenominacional ${ }^{2}$, o movimento se consolidou no cenário evangélico brasileiro, tornando-se famoso entre jovens de diferentes igrejas e correntes teológicas, e conhecido mesmo em meios seculares. Na internet, o Eu Escolhi Esperar conta com mais de 3 milhôes de seguidores, apenas em sua página oficial no site Facebook ${ }^{3}$, mas também não faltam páginas, grupos e memes não-cristãos que utilizam o lema para piadas, como as diversas páginas e grupos denominados "Não Escolhi, Mas Estou Esperando". Assim, eu escolhi esperar se tornou um bordão difundido dentro e fora do universo evangélico, e que neste circula atravessando diferentes

2 Chama-se de ministérios interdenominacionais as organizações religiosas que não se vinculam a uma igreja (denominação) específica, mas atuam realizando eventos (nesse caso seminários, acampamentos e festas) em diferentes igrejas, mediante convite. Tais ministérios costumam ser ligados mais a figuras de pastores(as), se destacando por seu foco em causas específicas, como amor e sexualidade no caso do Eu Escolhi Esperar. É interessante notar que esse tipo de organização, bastante vinculada à internet, garante a esses movimentos ampla penetração em diversas tradiçóes do amplo contexto evangélico.

3 Página oficial: "Eu Escolhi Esperar”, no Facebook: <https://www.facebook.com/euescolhiesperar/?fref=ts $>$. No mesmo site, o movimento conta ainda com um grupo oficial fechado (disponível em: <https://www.facebook.com/groups/grupoEEE >). O perfil no site de microblogues Twitter, onde a campanha surgiu, pode ser acessado em <https:// twitter.com/escolhiesperar>. Links acessados em: 20 jul. 2017. 
tradiçóes, igrejas, redes e sujeitos, extrapolando o escopo do próprio movimento. Através de noçóes como escolha, espera e pureza sexual, o movimento tem produzido novos sentidos para a interdição ao sexo antes do casamento, um dogma tradicional do cristianismo. Contudo, a ideia de escolher esperar também é ressignificada pelos sujeitos que a ela aderem a partir de seu contato com o movimento, de seus trânsitos religiosos e de suas vivências afetivo-sexuais.

A pesquisa de campo se estendeu durante os anos de 2016 e 2017, e consistiu na frequência a eventos realizados pelo Eu Escolhi Esperar, ou com a participação do pastor Nelson, nas cidades de São Paulo e Campinas. Neste período, também frequentei grupos de jovens e cultos de igrejas diferentes em Campinas. De forma mais sistemática, acompanhei encontros de jovens da igreja Cristo Salva e do "Girls - Garotas com Propósito" - um grupo formado por mulheres jovens de diferentes denominaçóes. Em menor medida, frequentei ainda reunióes de jovens da Igreja Batista e Quadrangular. Assim, mantive contato por meio de conversas e entrevistas com interlocutores de diferentes denominações, incluindo fiéis e líderes de jovens. Quer eles se considerassem ou não seguidores do movimento Eu Escolhi Esperar, de forma geral, este era conhecido e referenciado por todos. Paralelamente, acompanhei os conteúdos do movimento em suas páginas, grupos e canais através da Internet, bem como a cobertura midiática a seu respeito.

Neste artigo ${ }^{4}$, pretendo refletir sobre como o amor vem sendo mobilizado nos discursos do movimento em defesa da abstinência pré-conjugal, sendo a felicidade amorosa a recompensa para quem escolhe e suporta a espera, ao passo que esta passa a ser uma questão não só de pecado, mas, sobretudo, de inteligência emocional. Pretendo demonstrar como os discursos evangélicos em torno dos relacionamentos afetivo-sexuais possuem ligações com a "cultura terapêutica" (Illouz, 2011) e o "pensamento amoroso" (Esteban, 2011) contemporâneos, ainda que visem, em última instância, a produção de famílias heterossexuais,

4 Agradeço a Adriana Piscitelli, minha orientadora, e à Iara Beleli, Tiago Vaz, Natália Padovani, Raquel Banuth, Julyanne Ribeiro, Cinthia Marques Santos, Monica Conrado e Lúcia Sestokas pela leitura generosa e debate prévio deste texto.

Debates do NER, Porto Alegre, ANo I9, N. 34, P. 25 I-277, Ago./Dez. 20 i 8 
sólidas e indissolúveis, baseadas em papeis tradicionais de gênero. Como veremos, dessa articulação de diferentes campos discursivos, produzem-se códigos, convençóes e performances de gênero singulares, que atravessam as expectativas, buscas e trajetórias amorosas dos sujeitos.

Os estudos sócio-antropológicos sobre amor têm apontado, em geral, o vínculo entre a noção romântica de amor, surgida na Modernidade Ocidental, e a visão individualista de mundo (Viveiros de Castro; Benzaquim Araújo, 1977; Heilborn, 2004 entre outros), expressa, sobretudo, na associação entre amor, casamento e liberdade de escolha. Outros autores, como Esteban (2011), têm enfatizado o amor romântico enquanto matriz de produção de diferenças e desigualdades de classe, raça, etnia, sexualidade e gênero. Já Povinelli (2006), ressalta o lugar do amor, da intimidade e dos afetos como tecnologias de governo ocidentais, nos marcos do liberalismo e da colonização.

Nas últimas décadas, porém, o amor romântico vem coexistindo com a proliferação de modelos relacionais, que não necessariamente incluem a afetividade e podem ser bastante flexíveis. Dessa forma, a literatura recente tem considerado como os processos de mudança nas normatividades sexuais vêm sendo acompanhados por transformaçóes profundas na forma como o vínculo amoroso é vivenciado e concebido, colocando cada vez mais em questão o modelo do casal conjugal, hétero e monogâmico. Tais processos são influenciados por movimentos sociais que politizaram as relaçôes pessoais (Giddens, 1993), como os feminismos e movimentos LGBT, bem como por novas tecnologias midiáticas (Beleli, 2015), a indústria cultural e psicanálise (Illouz, 1997, 2011).

Reconhecendo a complexidade dos processos de mudança no campo das relaçôes afetivo-sexuais, seu atravessamento por relaçóes de poder, e a tensa convivência entre normatividades em disputa, busco compreender como os discursos evangélicos sobre amor se relacionam de forma ambígua a esses processos. Se por um lado, o Eu Escolhi Esperar busca produzir um "padrão cristão de relacionamentos", de forma contrastiva em relação a "cultura do mundo", ao mesmo tempo, sua pedagogia afetiva é profundamente atravessada por noçóes como "saúde emocional", advindas de campos não-religiosos. 


\section{INTELIGÊNCIA EMOCIONAL, CULTURA TERAPÊUTICA E GENÊRO}

"Quem aqui tá namorando? Quem aqui tá solteiro? Tô perguntando porque hoje eu vou orar por você e quando eu oro é forte! Deus traz a pessoa amada em 24 horas!"

É com essa frase que o pastor Nelson costuma abrir os seminários da campanha Eu Escolhi Esperar, provocando reaçóes entusiasmadas na plateia. A frase é emblemática por ajudar a reforçar a ideia de que seus seminários são destinados "a todos os que querem ser felizes no amor", porque, afinal, "esperar em Deus também é guardar o coração”. Ao explicar ao público, seja pessoal ou midiaticamente, do que se trata o Eu Escolhi Esperar, Nelson costuma dizer que "nós não somos uma campanha pela virgindade, um movimento de virgens, nós somos um movimento pela saúde emocional". Assim, o propósito do Eu Escolhi Esperar ultrapassa a defesa da castidade como obediência a um princípio bíblico e adquire contornos de pedagogia afetiva, articulando "saúde emocional" e "santidade sexual".

Tanto Nelson quanto outros membros da campanha estão constantemente evocando a necessidade de "falar abertamente sobre sexo nas igrejas", de orientar o jovem cristão para a sexualidade, assinalando que este ainda seria, em muitas denominaçóes, "um tema tabu". Mas essa necessidade se soma, no discurso do movimento, à carência de "inteligência emocional” no meio evangélico. Nesse sentido, os sentimentos amorosos exercem uma influência profunda, positiva ou negativa, sobre toda a vida. Os jovens seriam especialmente vulneráveis ao poder desestabilizador da frustração amorosa: Nelson afirma que esta é a causa da maior parte dos afastamentos de jovens das igrejas. A noção de saúde emocional aqui enunciada se relaciona a um padrão normativo acerca das formas de lidar com os sentimentos e relaçóes. Sobretudo, está em jogo a ideia de autonomia emocional: não ser emocionalmente dependente de alguém, ser "curado" em relação a "feridas emocionais do passado" e ser capaz de manejar as próprias emoçóes, refletindo racionalmente sobre elas. $\mathrm{O}$ amor e a paixão seriam sentimentos particularmente perigosos e que tendem 
a gerar sofrimento, do qual é preciso fugir. Para náo sofrer e ser feliz no amor, o caminho mais eficaz seria "esperar o tempo de Deus".

O amor não machuca ninguém, o que machuca é despertar o amor fora do tempo de Deus. Eu criei o Eu Escolhi Esperar porque me doía ver tantos jovens sofrendo tão cedo por amor sem precisar. Se você, jovem, não quer sofrer igual a todo mundo sofre, então você não pode viver como todo mundo vive. [Diário de campo, Fala de Nelson na Escola Bíblica Adolescente].

Não viver "como todo mundo vive" significa viver de acordo com um "padrão cristão de relacionamentos", expressado notadamente no conceito de "namoro cristáo", um modelo relacional que é constantemente evocado por diferentes sujeitos para distinguir suas práticas amorosas de práticas que seriam hegemônicas no contexto secular, isto é, "no mundo". O "namoro cristão" é caracterizado por um conjunto de convençóes mais ou menos flexíveis, que, com exceção da abstinência sexual pré-conjugal, podem variar de uma denominação para outra. A abstinência sexual, a heterossexualidade, a monogamia, a afinidade religiosa dos parceiros e o casamento como propósito final são seus pilares centrais. Sobre este último ponto, é importante ressaltar que, como dito diversas vezes por Nelson e por vários interlocutores, "crente não namora pra se divertir, crente namora pra casar". Ou seja, o namoro é concebido como uma fase na qual se deve conhecer profundamente o parceiro, avaliando se este é ou não adequado para a constituição de uma família, uma vez que, dada a interdição do divórcio ${ }^{5}$, o vínculo matrimonial é indissolúvel.

5 O divórcio é, na verdade, um tema polêmico e não consensual. Embora sua interdição siga sendo reconhecida, e expressa, ao menos e teoria no não reconhecimento de novos casamentos pós-divórcio, há exceçôes à regra, como em casos de adultério. Na prática, porém, diversas outras justificativas para ser usadas para legitimar um segundo casamento, como o fato de não ser evangélico à época do divórcio, casos de violência doméstica ou ainda quando a pessoa "sente" que Deus autoriza o relacionamento.

Debates do NER, Porto Alegre, ANo I9, N. 34, P. 25 I-277, Ago./Dez. 20 i 8 
Assim, durante o Seminário Inteligência Emocional, do qual acompanhei as apresentações na cidade de São Paulo desde 2016, o pastor Nelson ensina os jovens a escolherem entre "os dois caminhos para ser feliz no amor: o mais fácil e o mais dificil". O caminho mais fácil não seria o mais cômodo, o mais confortável, mas seria, segundo o pastor, o mais "seguro". Seguir esse caminho implica escolher seguir a "vontade de Deus" em detrimento da própria vontade e confiar que "os planos de Deus são melhores que os seus". Entretanto, nem só de preceitos bíblicos é composta essa distinçáo entre o "caminho fácil" e o "difícil". Ao contrário, a única prescrição relacionada ao pecado é a da "imoralidade sexual". Não saber distinguir entre paixão e amor; "insistir em amor não correspondido", "correr atrás de ex", se envolver em "rolos" e "ficar", isto é, se relacionar sem a intençáo de estabelecer um vínculo amoroso, seriam escolhas pelo caminho mais difícil.

Tem-se entáo uma mistura de preceitos bíblicos com um repertório terapêutico típico de livros de autoajuda amorosa, resultando na conformação de uma pedagogia afetiva na qual as noçóes de "tempo" e "espera" são centrais: há um tempo determinado por Deus para todas as coisas, pelo qual se deve esperar. A espera é vista como uma escolha racional feita a partir de um cálculo inteligente que envolve os riscos e consequências, custos e benefícios de uma relaçáo amorosa. Mais do que isso, ela seria uma escolha que minimizaria os riscos e garantiria a felicidade.

Preocupada com os imbricamentos entre capitalismo e sentimentos na contemporaneidade, Illouz (2011) assinala que a penetração da psicologia no cotidiano, entrelaçada ao ideário do feminismo liberal e ao mercado, fez com que surgisse, no século XX, uma cultura afetiva profundamente especializada: a "cultura terapêutica". A partir da defesa de noçóes como autonomia, igualdade, comunicação, autorrealização, homens e mulheres foram levados a se concentrar cada vez mais intensamente em seus sentimentos, seja no trabalho ou na vida familiar: os afetos tornaram-se objetos a serem pensados, calculados e manejados. Outro autor que considera a crescente influência cotidiana dos "saberes psi” é Rose (1999), para quem estes constituem novas tecnologias de governamentalidade, compatíveis com 
os ideários liberais de autonomia e liberdade. Através da proliferação desse conjunto de saberes, técnicas e linguagens especializados, somos levados a nos voltarmos cada vez mais sobre nossas subjetividades, nos tornando seres intensamente subjetivos e cada vez mais habilitados a agir sobre nossos corpos e almas em busca de felicidade e saúde. O que está em jogo não é mais libertar-se das amarras sociais, mas sim libertar-se de si mesmo, dos próprios constrangimentos psicológicos. Trata-se da produção de sujeitos autogovernáveis, responsáveis pela própria liberdade, que devem viver e construir o sentido de suas vidas, não segundo constrangimentos externos, mas segundo escolhas individuais exercidas face a um projeto de realização pessoal. Assim, a abstinência deixa de ser vista como uma norma imposta, para ser mobilizada na constituição de subjetividades capazes de escolher.

Contudo, a retórica terapêutica do Eu Escolhi Esperar é fortemente atravessada por gênero, se baseando na noção de que homens e mulheres se relacionam, sentem e expressam seus sentimentos de forma naturalmente distinta. Assim, os conselhos para atrair e manter uma relaçáo sáo diferenciados de acordo com gênero. Por exemplo, ao falar sobre carência afetiva, o pastor Nelson diz que:

Esse é um erro que atrapalha principalmente as mulheres. As mulheres estão tão carentes que se jogam nos braços de qualquer um, daquele que tem boa lábia, bom papo, que sabe mexer com as emoçôes. Porque homem quando presta, quando vai ser um bom marido, ele quer o seu coração e não o seu corpo. [...] Mas quando a carência sobe, a autoestima desce, e a pessoa se contenta com qualquer coisa. [Diário de Campo, Seminário Eu Escolhi Esperar].

Por outro lado, quando os conselhos se focam especificamente para os meninos, eles são geralmente a respeito do número de parceiras e da preservação sexual.

Agora que eu já falei pras meninas, vou falar pros homens. [...] Não existe essa de mulher irresistivel não, o que existe é homem frouxo! Isso é desculpa, pureza e santidade sexual também são para os homens! [Diário de Campo, Seminário Eu Escolhi Esperar]. 
Durante um dos seminários, o pastor enfatiza ainda que homens e mulheres possuem imaginários diferentes sobre o casamento, reforçando a ideia de que mulheres seriam mais românticas enquanto homens seriam mais sexuais:

Mulher acha que casamento é a Disneylândia, porque acredita em conto de fadas, em principe. Homem acha que casamento é igual Brasileirinhas ${ }^{6}$, que é sexo o dia inteiro. Olha pra mulher já pensando "quando a gente casar, lá em casa..." [...] - todos riem e aplaudem, principalmente as mulheres. [Diário de campo, Seminário Eu Escolhi Esperar].

Ao analisar a retórica do "controle emocional", Lutz (1996) ressalta que a noção de que as emoçóes devem ser controladas, ou ao menos gerenciadas, opera de forma similar ao dispositivo de sexualidade (Foucault, 1979), construindo as emoçóes enquanto instintos naturais, essências psicológicas constrangidas pela sociedade, e classificando-as, segundo um modelo biomédico, em formas saudáveis e não saudáveis. Discursos médico-científicos, assim como sensos-comuns difundidos, produzem ligaçôes entre mulheres e descontrole emocional, bem como produzem a ideia de que emoçóes são, paradoxalmente, responsáveis pela fraqueza de indivíduos ou capazes de despertar uma força incontrolável, sendo, portanto, duplamente perigosas. Alves (2005) também compreende a "afetividade" como um dispositivo de poder contemporâneo, apontando a crescente centralidade discursiva que os afetos vêm ganhando na nossa sociedade. A autora demonstra como livros de autoajuda voltados à conjugalidade, ao colocar os afetos em discurso, se baseiam em diferenças concebidas como fisiológicas e hormonais para dirigir conselhos específicos a homens e mulheres, vistos como seres naturalmente dicotômicos. A partir da ideia de que as mulheres são hormonalmente inclinadas à sentimentalidade, esta literatura circunscreve a elas a responsabilidade sobre a gestão dos sentimentos e o cuidado da vida conjugal. Nestas obras, o amor é mensurado em termos individualistas e a conjugalidade é

${ }^{6}$ Referência à famosa produtora brasileira de filmes pornográficos. 
representada como um passo necessário ao aprimoramento do eu, no bojo de dicotomias entre amor e sexo, afeto e razão, cognição e emoção.

No caso da pedagogia afetiva do Eu Escolhi Esperar, observa-se que, embora haja um reforço da associação entre masculinidade e desejo sexual, feminilidade e emocionalidade (os dois devendo ser submetidos ao autocontrole), busca-se envolver ambos, homem e mulher, no cuidado com a relação, cabendo também aos homens a participação na gestão comunicativa do namoro. A produção de masculinidades orientadas à conjugalidade também se expressa no esforço de propagação do "príncipe" hiper romântico como modelo de masculinidade adequada. Esforço esse que modela tanto o "capital afetivo" (Illouz, 2011) deles, quanto as expectativas amorosas delas, ajudando a reafirmar a máxima de que "esperar vale a pena".

\section{CONTOS DE FADA E FINAIS FELIZES: PERFORMANDO GÊNERO E AMOR ROMÂNTICO}

O Programa Hora do Faro, da emissora Rede Record de Televisão, apresentado por Rodrigo Faro aos domingos, possui um quadro chamado "Preciso dizer que te amo", cujo foco são declaraçóes surpresas de amor. Em 8/3/2015, Nelson Júnior, idealizador do Eu Escolhi Esperar, participou do quadro, no qual declarou seu amor por Angela, com quem é casado há vinte anos ${ }^{7}$. Rodrigo Faro anuncia o quadro se referindo a Nelson da seguinte forma:

Um homem que teve na vida uma unica mulher. Um homem que ele escolheu, por escolha própria, ele abriu mão de outros relacionamentos e quebrou um tabu nos dias de hoje: esse homem decidiu se casar virgem. Tudo isso porque ele tinha uma única certeza: aquela era a sua mulher, a única mulher pra sua vida inteira.

7 O vídeo da participação está disponível online no endereço: <https:/www.youtube.com/ watch?v=jU2JoijVnzg>. Acesso em: 7 jan. 2018. 
Em seguida, a repórter que entrevistará Nelson arremata:

É, Rodrigo, quem diria que em pleno século XXI a gente ouviria falar de uma história como essa, que foge totalmente dos padröes de relacionamento moderno, né?

Aludindo sempre ao bordão "vale a pena esperar por aquilo que vai durar uma vida inteira”, o pastor narra a história de como conheceu, se apaixonou e se casou com Angela, destacando o fato de que ela, no princípio, o enxergava apenas como um amigo. Em uma simulação encenada por atores, o vídeo mostra a cena em que Nelson teria se declarado a Angela e lhe dito: "eu escolhi você pra ser a mulher da minha vida”. Após uma série de tentativas de conquista-la, que incluíram presentes, flores e bombons, Angela só disse sim a Nelson quando este preparou, com ajuda de sua irmá, uma surpresa com um carro de som para ela em frente à escola onde estudava. Enquanto fotos da vida do casal são mostradas, Nelson diz à repórter, enfaticamente: "eu não acredito em conto de fadas, mas acredito em finais felizes". É a música ${ }^{8}$ que o carro de som tocou nesse dia, há duas décadas atrás, que Nelson canta para Angela no palco do programa. De joelhos e chorando, ele a pede novamente em casamento, para a renovaçáo dos votos. Ao encerrar o quadro, Rodrigo Faro deseja vida longa ao casal, e pede para que eles "continuem falando $e$ divulgando a coisa mais importante que existe no mundo, que é o amor".

O vídeo da participação de Nelson e Angela no "programa do Faro" é exibido em todos os seminários do Eu Escolhi Esperar, antes do início e durante os intervalos, nos telóes das igrejas por onde o movimento passa. $\mathrm{O}$ pastor também costuma contar a "história de amor" do casal com frequência, acrescentando um ou outro pormenor e arrancando reaçóes entusiásticas da plateia - especialmente a feminina - às vezes de riso, às vezes mais emocionadas. Em uma dessas ocasióes, Nelson descreve com detalhes a noite em que se declarou a então melhor amiga. A cada frase que diz, a plateia reponde com aplausos e suspiros. Contudo, um momento é marcado por agitação

8 A canção "Princesa” é do cantor gospel Marcos Goés e pode ser consultada em: <https:// www.letras.mus.br/marcos-goes/1023168/\#radio:marcos-goes>. Acesso em: 3 jan. 2017.

Debates do NER, Porto Alegre, ANo i9, N. 34, P. 25 I-277, AGo./DeZ. 20 i 8 
especial: aquele em que ele, mudando o tom de voz, conta ter dito a Angela que "pros outros você pode ser só mais uma opção, mas pra mim, pra mim você não é só uma alternativa, você é minha escolha".

Além de Nelson, é comum que outras personalidades públicas evangélicas, como cantores gospel que participam dos seminários, contem seus testemunhos de como conheceram, se declararam ou pediram em casamento suas namoradas e esposas. Geralmente, o roteiro envolve a superação de desafios pessoais ou da relação, declaraçóes e propostas de casamento públicas (que podem acontecer inclusive durante os eventos do Eu Escolhi Esperar) e a realização de uma grandiosa festa de casamento ou da viagem de lua de mel dos sonhos. Ainda durante um dos seminários, o pastor Nelson se dirige especificamente aos homens da plateia ao dizer que:

Vou falar uma outra coisa agora! Pureza e santidade também é pra homem! É dificil? É dificil. Eu sei que você já ouviu muito que homem de verdade é o homem que conquista várias mulheres. Mas isso é mentira. Se você é assim, você não é homem de verdade, você é um covarde [sendo muito aplaudido pelas meninas]. A maior covardia que um homem pode fazer por uma mulher é conquistar ela sem ter intençäo de amar. O homem de verdade não é o que tem várias mulheres na vida, é aquele que abre mão de muitas pra ficar com uma só! [Diário de campo, Seminário Eu Escolhi Esperar].

A esse príncipe que conquista com flores, declaraçôes públicas na TV, presentes e frases de efeito, que "abre mão de muitas por uma única", corresponde uma princesa a qual ele deve se esforçar para conquistar, cortejar e honrar. Enquanto o príncipe se define por seu romantismo, sua destreza na conquista e sua santidade sexual, a princesa se define por seu valor. Sobretudo, ela não é princesa por ter um príncipe, mas por ser "filha do Rei (Deus)", o que a dá um valor intrínseco. Embora todas as mulheres cristãs sejam uma "jóia" para Deus, é preciso viver de acordo com esse valor, acreditar nele e se valorizar, fazendo com que os homens também a valorizem. "Se valorizar" significa não apenas cuidar da autoestima e manter um senso de autodignidade, mas implica formas específicas de interação amorosa, sobretudo no 
flerte. Uma vez que se tenha certeza de "merecer o melhor", dado seu alto valor, não só deve-se manter a pureza sexual, como deve-se ser altamente seletiva quanto aos parceiros com quem se relaciona.

A ideia de que as mulheres não devem "correr atrás" é bastante comum e aparece em uma série de discursos de aconselhamento, além do Eu Escolhi Esperar, e falas de interlocutores sobre a forma adequada de proceder na busca por um parceiro. Caberia ao homem tomar iniciativa e demonstrar interesse, colocando-se como candidato e cortejando sua pretendente. Já o papel feminino seria o de adequar seu comportamento, avaliar e selecionar parceiros, sendo o grau de seletividade um critério moral: quanto mais uma mulher valoriza a si própria, maior seu grau de seletividade e mais valorizada ela será pelos homens.

Esses tipos de concepçóes sobre o dualismo masculinidade e feminilidade possuem aproximaçóes com a literatura secular de autoajuda (Alves, 2005). A conduta da mulher no flerte é vista como sendo representativa do valor que ela se dá. Quando interessada em alguém, a mulher deve proceder buscando estabelecer um vínculo de amizade, através do qual demonstrará os pontos positivos de sua personalidade, mas jamais deve ser direta em suas intençôes, "roubando" do homem a sensação da conquista. Essa norma estaria fundamentada em princípios bíblicos, já que na Bíblia todas as histórias de casamento teriam se originado da iniciativa masculina, mas também na noção de que homens e mulheres possuem "estruturas emocionais" distintas: o homem seria "instintivamente" um caçador, sendo preparado para lidar de forma racional com as negativas, enquanto mulheres seriam demasiado sentimentais, e ouvir um não produziria nelas efeitos devastadores, como traumas e complexos de inferioridade.

Esteban (2011) aponta para a possibilidade de pensar as relaçôes entre amor romântico e a matriz sexo/gênero/desejo (Butler, 2003), ao apontar este como um "regime emocional" que produz performativamente "homens e mulheres como pessoas opostas, complementares, hierarquizadas" (Esteban, 2011, p. 50). Butler (2003) parte da noçâo de performatividade para descrever a forma como o sexo e o gênero são produzidos através da repetiçáo incessante e reiterativa de normas dentro de um marco regulatório. Dessa forma,

Debates do NER, Porto Alegre, ANo I9, N. 34, P. 25 I-277, Ago./Dez. 20 I 8 
o gênero "se materializa" através de atos, gestos, desejos, como sendo a manifestação de uma natureza substancial do corpo, o sexo. Nesse sentido, declaraçôes de amor, surpresas, presentes e suas narrativas públicas são atos performativos que produzem e sustentam o que é ser "homem de verdade", ou ainda, a "princesa" como ideal de feminilidade, ao mesmo tempo em que os constrói como expressōes de estruturas fisiológicas, psíquicas e corporais.

Em suma, enquanto o flerte feminino precisa ser contido, sutil, e o mais discreto possivel, de forma a demonstrar o quanto a mulher se valoriza, o flerte masculino é exagerado, chamativo, público. Trata-se, assim, de modelar o gênero e o amor, de forma articulada, promovendo concepçóes cristấs sobre o que é ser homem, o que é ser mulher e o que é amar. A retórica dos finais felizes, promovida por líderes carismáticos e seus testemunhos, instiga os jovens a acreditarem que o par perfeito, preparado por Deus, os encontrará em algum momento, e que é possível viver um amor ideal, duradouro e ritualizado em grandes atos apaixonados, mesmo em tempos de "relaçôes descartáveis". Essa mensagem impacta especialmente as meninas, para quem a busca por um parceiro no interior das igrejas costuma ser muito difícil: para passar pelas angústias e ansiedades da espera, é preciso alimentar a esperança de que príncipes existem e de que "Deus tem um plano para todos".

\section{"O VERDADEIRO AMOR ENCONTRARÁ O CAMINHO": ESPERA, SOLIDÃO E BUSCAS AMOROSAS}

O que acontece, entretanto, quando o príncipe prometido parece demorar a chegar? Ou quando a espera parece durar em demasia? Por trás da proliferação de ministérios, cultos, páginas de internet, livros etc., destinados a aconselhamento amoroso para solteiros, reside uma preocupaçáo atual das igrejas: a dificuldade dos jovens, principalmente entre mulheres, em estabelecerem relacionamentos. Não é só a santidade que é vista como uma questáo fundamental para a "geraçãa" atual de jovens evangélicos, mas também o amor. Daí o pastor Nelson reiterar sempre que envolvimentos românticos sáo um 
dos principais motivos que levam os jovens a se afastarem da vida cristâ, seja por decepçóes com parceiros da igreja, seja em busca de parceiros "de fora”. Produzir vínculos amorosos "sadios" e duradouros entre os jovens, capazes de resultar em casamentos felizes, é visto como um desafio para as igrejas hoje, na medida em que é fundamental para a produção de famílias e, consequentemente, para a manutenção e crescimento de seu corpo de membros.

Durante a pesquisa de campo, quase todos os interlocutores com quem conversei, sobretudo as interlocutoras, foram categóricos ao apontar a grande diferença numérica entre homens e mulheres nas igrejas como um fator que dificultaria a constituição de relacionamentos amorosos. Mesmo nos eventos do Eu Escolhi Esperar, pude observar sempre uma expressiva maioria feminina ${ }^{9}$. A literatura sociológica que trata sobre as articulaçóes entre gênero e religião tem se preocupado em explicar essa assimetria e seu impacto na estrutura eclesial das denominaçóes, bem como as conexóes entre feminilidades e conversão religiosa (Machado, 1996; Couto, 2002). Mas do ponto de vista das relaçóes afetivas, a desigualdade numérica transforma a busca por um parceiro em um desafio que, no caso das mulheres, pode gerar angústias, frustraçóes e até deslizes normativos, tais como afastamentos ou relaçôes de jugo desigual - forma como são chamados os relacionamentos em que um dos parceiros não é convertido.

Nos seminários do Eu Escolhi Esperar, Nelson costuma apresentar dados estatísticos que comprovariam que a maior parte dos casos de jugo desigual seriam vivenciados por mulheres (segundo ele, 80\%). O pastor também exorta as meninas para que não se iludam acreditando que é possível que o namorado se converta por amor a elas. Ao longo da pesquisa, ouvi diversas histórias de meninas evangélicas (inclusive algumas de minhas interlocutoras) que se envolveram em relaçôes de jugo desigual com finais

9 No Eu Escolhi Esperar, por exemplo, essa maioria é de 65\%, segundo dados do próprio movimento. Fonte dos dados: <http://www.msn.com/pt-br/estilo-de-vida/relacionamentos/eles-escolheram-esperar-sexo-s\%C3\%B3-depois-docasamento/ar-BBbWP6R>. Acesso em: 5 jun. 2015. 
malsucedidos: ou a história terminava com coraçóes partidos, às vezes com a menina abrindo mão do "princípio da santidade", ou com esta se afastando da igreja por causa do namorado. São raras as histórias com finais felizes, ou seja, aquelas em que o homem acaba "aceitando Jesus". Apesar de haver um certo reconhecimento de que procurar um parceiro fora da igreja é uma saída encontrada por muitas mulheres, no geral, esse tipo de relação é contraindicada como uma relação que não teria futuro, dada a incompatibilidade de valores do casal.

O baixo número de homens nas fileiras das igrejas não é, entretanto, o único fator a dificultar a procura por um parceiro: a própria forma como o flerte é concebido e as expectativas de gênero que ele implica, podem colocar as mulheres em desvantagem. São comuns reclamaçóes das mulheres sobre homens que não "têm atitudes de homem", ou seja, não demonstram interesse ativa e diretamente, como é esperado deles. Assim, os desencontros entre as expectativas de gênero, colocadas por padróes idealizados e desiguais, tornam-se mais um obstáculo na busca pelo amor. Contudo, embora a ideia de que a mulher não deva tomar a iniciativa seja bastante difundida (enquanto norma prescrita, ou através da noção do ideal de feminilidade a ser cortejada e conquistada), ela não pode ser generalizada, pois nem todos os líderes ou fieis a aderem . Tampouco pode-se afirmar que as mulheres adotam uma atitude passiva no flerte amoroso. Ao contrário, como demonstram as histórias e falas de minhas interlocutoras, as mulheres jogam com os códigos de relacionamento, mobilizando a seu favor estratégias para burlar a assimetria numérica de suas igrejas, que incluem desde a participação em eventos realizados em outras igrejas (como, por exemplo, seminários, acampamentos, datas temáticas) ${ }^{10}$ até a atenção aos novos convertidos ainda solteiros.

${ }^{10}$ Os próprios eventos do Eu Escolhi Esperar são uma “ótima oportunidade para conhecer alguém de Deus”, como o pastor Nelson ou Lincon costumam dizer durante os seminários e festas, embora ninguém do público com quem eu tenha conversado até hoje admitiu ter essa intenção ao comparecer às reunióes.

Debates do NER, Porto Alegre, ano I9, N. 34, P. 25 I-277, Ago./Dez. 20 i 8 
Eu conheci Alice (25 anos, fonoaudióloga) em 2016, durante um evento acadêmico. Junto de sua família, Alice se converteu aos 15 anos, passando a frequentar a Igreja Batista. Durante a faculdade, porém, ela enfrentou um momento de estremecimento em sua fé, relacionado a inquietaçóes ocasionadas pelo fato de quase todas as suas amigas terem começado a namorar ou ficar com rapazes, enquanto ela permanecia solteira. Nesta época, Alice se envolveu com rapaz "do mundo", uma experiência da qual ela se lembra com pesar, pois se sentiu "enganada”, já que as intençóes dele eram apenas sexuais, embora considere que ele tenha fingido buscar uma relação séria.

Até o ano passado, porém, Alice nunca havia namorado. Assim como com outras interlocutoras solteiras, nossas conversas giravam frequentemente em torno das dificuldades de se encontrar um parceiro no contexto das igrejas. Em diversos momentos, ela me contou sobre as angústias que enfrentava em relação à sua vida amorosa, de tentativas de conquista frustradas até a incerteza de que um dia iria, enfim, encontrar quem acredita ser o parceiro ideal. Em suas palavras, "um homem capaz de amar a mulher como Cristo amou a igreja e, inclusive, de se sacrificar por ela", alguém que mereça receber, após o casamento, o "presente" de sua virgindade e com quem ela passará o resto de sua vida.

É assim que, em nossa última conversa, Alice me confidenciou que está "a fim " de um menino que chegou há pouco tempo na igreja, mas ainda não sabe se ele corresponde ao interesse. Eles estão muito próximos, mas ela questiona se, para ele, o interesse só estaria no âmbito da amizade, então procura desvendar o que julga serem "sinais", como o tempo de resposta das mensagens trocadas via WhatsApp, a roupa que ele usa quando vão se ver, se ele está bem arrumado ou não. Quando pergunto se ela não poderia, afinal, lhe perguntar diretamente sobre suas intençóes, ela diz que poderia, porém, acha melhor não. Ela me conta que na igreja "geralmente tem isso de ser o homem quem toma a atitude, né”, mas que não é esse o motivo pelo qual ela prefere esperar: "é mais por causa da minha timidez mesmo, e porque eu já fiz isso duas vezes e as duas deram muito errado, foi muito ruim". 
A história de Alice é particularmente marcada pelas angústias de ainda estar esperando. Por um lado, ela demonstra como a espera náo deve ser entendida como um período de passividade. Ao contrário, Alice ao mesmo tempo em que entende esse momento como ideal para se auto-aprimorar, investir em sua carreira e em sua espiritualidade, também se engaja ativamente, ainda que de forma não declarada, para cativar os rapazes por quem se interessa. Em contrapartida, o fato de que sua busca até agora não foi bem-sucedida, abre uma questáo para a qual náo parece haver espaço no movimento Eu Escolhi Esperar: e se "o verdadeiro amor [não] encontrar o caminho"? O que acontece com a espera quando se abre a possibilidade de que esta não seja recompensada? Ao fim de uma de nossas conversas, Alice me revela que perguntou ao pastor se todas as pessoas estavam predestinadas a casar, ao que ele teria respondido que não havia nada na Bíblia que pudesse ser interpretado dessa forma, entáo náo haveria como afirmar que o casamento era, afinal, a vontade de Deus para todos.

Dessa forma, Alice coloca em suspenso a máxima de que haveria um final feliz guardado para todos aqueles que escolhem esperar. Contudo, estar solteira pode ser algo espinhoso para grande parte das mulheres evangélicas. A começar por se tratar de um contexto no qual o casamento e a família são vistos como destinos naturais, locus por excelência da realizaçáo pessoal de homens e mulheres. Além da pressão social, mulheres que não se casam tendem a ficar deslocadas dos grupos sociais da igreja: por um lado, não se sentem mais a vontade no grupo de jovens, uma vez que possuem mais idade do que a maioria dos outros "jovens", e, por outro, ficam desconfortáveis nos grupos para mulheres, pois nestes predominam as casadas.

Se para as mulheres e, em menor medida, para os homens solteiros, a espera significa um exercício de gestáo de si e de forte controle emocional (seja para suportar a solidáo, seja para conquistar um par), para aqueles que vivenciam um namoro cristão, essa pedagogia afetiva adquire outros contornos, relacionados à manutenção da relação, à administraçáo das diferenças e conflitos, à comunicaçáo e conhecimento mútuo do casal, de forma a minimizar as chances de falha do futuro casamento. 


\section{"DEUS NÃO UNE PESSOAS, DEUS UNE PROPÓSITOS": MODELOS DE RELACIONAMENTO, NEGOCIAÇÃO DA INTIMIDADE E CONCEPÇÓES DE AMOR}

Laura tem 26 anos, já foi a seminários do Eu Escolhi Esperar e usa no pulso uma pulseirinha do movimento. Ela conta que, mesmo antes de "aceitar Jesus", há dois anos, sempre acreditou em se guardar sexualmente para o grande amor de sua vida. Contudo, quando conheceu Fernando, seu atual noivo, Laura e ele não eram mais virgens. Se conheceram na Igreja Cristo Salva, uma igreja pequena num bairro da periferia de Campinas. De uma amizade profunda e sem reservas, na qual compartilhavam segredos e se ajudavam a "crescer na fé", nasceu o interesse amoroso.

Entretanto, meses de brincadeiras, indiretas e carinhos se passaram sem que Fernando tomasse a inciativa de tornar claras suas intençóes. Até que Laura decidiu pôr as coisas em pratos limpos e intimou Fernando, através de uma mensagem sms, para uma conversa séria. Ele justifica a demora em tomar uma atitude mais direta, dizendo que tinha medo de "se prender emocionalmente" devido às "bagagens" emocionais que carregava do passado. "Eu falei, eu não quero mais ser emocionalmente dependente, eu quero ter um relacionamento sadio onde eu faça a pessoa feliz e a outra pessoa me faça feliz também".

Laura conta que, no jantar em que foi pedida em namoro, Fernando fez uma lista minuciosa daquilo que considerava como seus os próprios defeitos, sendo "totalmente transparente" sobre quem ele era e o que esperava da relação, bem como o que queria para o futuro dos dois. Ao mesmo tempo, ele ressaltou que a tinha escolhido pois via nela "todas as qualidades que buscava em sua futura esposa, na mãe de seus filhos, tudo que ele realmente esperava de uma mulher". O casal ainda definiu, nessa primeira conversa, quais seriam os limites da intimidade física no namoro. Nas palavras de Fernando:

Eu falei tudo que eu acreditava, da forma como eu queria conduzir o relacionamento, que eu não abria mão de santidade, que [...] eu queria realmente fazer algo totalmente diferente de tudo aquilo que eu já tinha vivido. [Entrevista Fernando e Laura] 
"Algo totalmente diferente", para Fernando e Laura significou optar por um namoro sem sexo, mas também sem beijo na boca - essa forma de namoro é conhecida no meio evangélico como corte. Inicialmente, a ideia era que eles apenas "orassem juntos" por 3 meses, para receber a "confirmação de Deus" de que a relação estava de acordo com a vontade divina. O "orar juntos" é uma fase que antecede a oficialização da relação diante da família e da comunidade da igreja, em que a ausência de carícias físicas é vista como fundamental para que "as vontades da carne" não impeçam o casal de "ouvir a voz de Deus" e ponderar sobre a continuidade da relação. Laura e Fernando, entretanto, mesmo depois dos 3 meses de oração, depois de pedirem a bênção do pastor, e de Fernando pedir a mão de Laura a seus pais, decidiram que seguiriam com o namoro de corte e que dariam seu primeiro beijo apenas no altar, no momento do casamento. Nas palavras de Laura:

Nossa, menina, depois dos 3 meses, eu queria muito beijar ele! Ai, [a gente combinou] "vamos se beijar no noivado". Ai tipo assim, até chegar no noivado [...] a gente teve várias conversas e a gente falou "ah, e se a gente se beijar no altar?". Foi assim, partiu dos dois ao mesmo tempo. O beijo deixou de ser uma prioridade. [...] Porque a gente conversava muito, muito. A gente tinha dois meses de namoro, e parecia, sem brincadeira, que a gente tinha dois anos. Porque a gente conversa demais, demais. $E$ falando de defeito, de qualidade, sabe, não era só aquele romancinho de coisas bobas, não. [...] A gente trocou as carícias os beijos por muita conversa e muita oração junto. E isso fez com que a gente desenvolvesse ali uma intimidade que eu acho que normalmente demora anos. [Entrevista com Fernando e Laura]

Embora Laura estivesse, no começo, muito ansiosa pelo beijo, ambos ressaltam a corte como uma escolha, algo que partiu deles mesmos, sem interferência ou sugestão do pastor ou de outras pessoas. Além disso, os dois consideram que não se beijar trouxe outros benefícios à relação, seja abrindo um maior espaço à comunicação e conhecimento sobre o parceiro, seja não dando margem a um outro tipo de intimidade que se deve manter afastada: a intimidade sexual. Como diz Fernando: 
Eu pensei assim: quando você beija, você pensa no que? [...] Um desejo, uma coisa leva a outra. [...] Eu não pensava na realização de beijar a boca dela, eu não pensava em mim, mas 'se eu beijar ela eu vou pensar no sexo, vai ser uma porta pra eu começar a tocar ela em outros lugares... Claro que assim, existe uma grande vontade, lógico que eu tenho. Mas eu creio que, a palavra de Deus diz assim, que o homem é o cabeça da casa, do seu lar né, então [...], eu mato a minha carne, o meu desejo, pra não expôr pra ela. Porque eu sei que é um desejo dela também, então eu mortifico isso. Como uma forma de demonstrar cuidado e carinho. [Entrevista com Fernando e Laura]

As falas de Fernando e Laura abrem espaço para compreendermos o "namoro cristáo" enquanto um modelo relacional estruturado sobre uma concepção própria de amor, assim como papeis e convençôes de gênero específicas. Por um lado, tem-se a constituição de uma relação baseada em um "ethos terapêutico" (Illouz, 2011), na qual o sexo e as carícias dão lugar à comunicação íntima, ao conhecimento do outro e ao autoconhecimento, fazendo com que, através de um processo de "racionalização comunicativa", os direitos e deveres, limites e termos da relação sejam abertamente negociados pelas partes. A santidade sexual é posta a serviço da busca por uma relação "sadia", cujo vínculo não se mantém por "dependência emocional", mas pela autorrealização de ambos no relacionamento, na qual o objetivo é "inspirar o outro a ser uma pessoa melhor".

Nas palavras de Laura, o amor é "uma decisão", uma escolha por aceitar a pessoa como ela é, mesmo conhecendo cada parte do outro, inclusive as piores. É esse conhecimento em profundidade - possível graças à pureza sexual, que acredita-se estar além de qualquer máscara - que garantirá a infalibilidade da futura relação conjugal e da nova família. No casamento, beijos, abraços e o sexo serão "a cereja do bolo", que coroará a espera e os sacríficos feitos em nome da construção do verdadeiro amor: aquele que ama o parceiro por quem ele é em sua verdade interior, e não se deixa enganar por desejos ou aparências carnais. Nesse sentido, Fernando considera que resguardar seu desejo para proteger a castidade de Laura é, além de uma 
forma de "honrá-la", um modo de demonstrar seu amor e de cumprir seu papel masculino como "cabeça da relação".

No entanto, essa contraposição entre amor genuíno e interesse sexual, ainda que temporária - uma vez que no casamento o que ganha espaço é a busca pela plenitude do prazer sexual -, pode não ser bem compreendida por pessoas que não professam a fé pentecostal. Fernando diz ter ouvido algumas vezes de amigos, familiares ou conhecidos, questionamentos quanto ao fato de se casar com uma mulher que nunca havia sequer beijado. Eles consideram esse tipo de estranhamento como instrínseco à "cultura de relacionamentos do mundo", na qual o que "se prega" é que o sexo é a essência de uma relação. Enquanto Fernando diz que "no mundo" as pessoas só estão preocupadas com a própria felicidade, para Laura trata-se de uma "visão totalmente distorcida", o exato oposto de uma relação concebida nos moldes cristãos:

[...] uma visão totalmente distorcida, onde no mundo primeiro você conhece. Ai, "hum, me atraiu". Ai você faz sexo e "ah, gostei, então vamos namorar". A gente não. A gente é: eu te conheço, você é legal e bonito, vamos nos conhecer melhor? E ai $o$ ato sexual termina, ele sela o ápice da intimidade máster, que é o casamento. É totalmente ao contrário. [Entrevista com Fernando e Laura]

\section{CONSIDERAÇÕES FINAIS}

A inteligência emocional, fruto da difusão cotidiana de "saberes psi" (Illouz, 1997; Rose, 1999) tem sido mobilizada pelo Eu Escolhi Esperar, articulada à preservação sexual, de forma a produzir sujeitos emocionalmente "saudáveis", capazes de refletir e fazer escolhas inteligentes sobre suas vidas afetivo-sexuais. Sendo a espera uma questão de "inteligência emocional", ela é, sobretudo, uma pedagogia afetiva fortemente atravessada por convençóes e imaginários de gênero. Assim, a feminilidade aparece associada à fragilidade emocional e a masculinidade ao instinto sexual predatório. Essas seriam características naturais que informam a maneira como homens e 
mulheres devem se portar no flerte: elas de forma contida, eles de forma direta, explicitando seu interesse através de rituais apaixonados. Entretanto, se a natureza é importante, ao supostamente constituir uma base de diferenciação irredutível entre homens e mulheres, na forma como sentem e expressam suas emoçóes, ela também pode ser ativamente trabalhada, por meio de tecnologias de si, as quais visam o autogoverno "da carne": príncipe e princesa são, dessa forma, indivíduos aptos a se autogovernarem em prol de seus projetos de realização amorosa.

A designação rígida de convenções de gênero pode levar, no entanto, a problemas maiores, sobretudo às mulheres, no que diz respeito à busca de um parceiro. Em um contexto no qual as mulheres predominam numericamente, e no qual relações com não-evangélicos não gozam de legitimidade (para não falar na impossibilidade de reconhecimento de relaçóes homossexuais), a prescrição da passividade feminina na conquista tende a dificultar ainda mais a situação das solteiras. A ideia do valor intrínseco e divino da princesa cristã, visto como uma fonte inquestionável de autoestima, é empregada de forma a aplacar a carência e as angústias da espera. Paralelamente, a performatização da figura do príncipe apaixonado, capaz de grandes atos públicos de amor, busca reafirmar a assertiva de que, ainda que a espera possa ser demorada, há um final feliz aguardando a todos, ao mesmo tempo em que produz um modelo do que é ser homem, a ser aprendido pelos seguidores. As expectativas geradas em torno das masculinidades assertivas e conquistadoras podem, no entanto, gerar desencontros e frustraçóes.

Contudo, se é por meio dos atos românticos performativos que os sujeitos se constituem como homens e mulheres, na incorporação do gênero, o que está em jogo é a produção de outra forma - cristã - de ser homem e de ser mulher. Na produção de diferenças entre masculino e feminino, uma outra diferença é produzida e reforçada a todo o tempo: a diferença entre "nós" e "o mundo". Ressalto, porém, que essa fronteira é tão porosa quanto tensa e sua produção é permeada por constante disputa de limites, numa complexa negociação que não pode ser simplificada como se a assimilação de lógicas 
seculares por igrejas fosse um processo contínuo, unidirecional e linear. O que temos é uma porosidade marcada por tensōes e pela busca de uma definição.

É assim que, se o namoro de Laura e Fernando (com sua "corte", a total ausência de contato físico e a ideia de honra feminina), nos remete ao "namoro à moda antiga" (descrito e analisado por Azevedo, 1986), ele também incorpora ingredientes fundamentais dos modelos de relação típicos da cultura terapêutica (Illouz, 1997, 2011), sobretudo a racionalização comunicativa, a auto-expressáo, a autonomia emocional. A corte, o namoro sem beijos, aparece em suas falas como uma escolha por um modelo de relação que trará benefícios futuros, minimizando os riscos de uma frustração. No "namoro com propósito", que segue as convençôes cristấs de "orar", pedir as mão aos pais, a bênçáo dos pastores, o noivado e o casamento, a castidade serve à comunicaçáo estreita, à avaliaçáo dos sentimentos e da relaçáo e ao conhecimento mútuo. Para Fernando, o autocontrole sobre sua natureza sexual é ainda uma questão de cuidado para com a santidade e a honra de Laura, uma expressão de seu amor, cujo fundamento é o auto-sacrifício. Relembro aqui as palavras de Alice, para quem o homem ideal é aquele "capaz de amar sua esposa como Cristo amou a igreja", ou seja, com um amor sacrificial. No entanto, como afirma a passagem bíblica citada por Alice, amplamente conhecida, esse amor, pronto a entregar a vida em prol do outro, é a contrapartida do homem à submissão feminina.

As mulheres sejam submissas a seus maridos, como ao Senhor, pois o marido é o chefe da mulher, como Cristo é o chefe da Igreja, seu corpo, da qual ele é o Salvador. Ora, assim como a Igreja é submissa a Cristo, assim também o sejam em tudo as mulheres a seus maridos. Maridos, amai as vossas mulheres, como Cristo amou a Igreja e se entregou por ela, para santificá-la, purificando-a pela água do batismo com a palavra, para apresentá-la a si mesmo toda gloriosa, sem mácula, sem ruga, sem qualquer outro defeito semelhante, mas 
santa e irrepreensível. Assim os maridos devem amar as suas mulheres, como a seu próprio corpo. Quem ama a sua mulher, ama-se a si mesmo. ${ }^{11}$

É a essa passagem que Fernando se refere ao dizer que, "como cabeça da relação”, precisa honrar e cuidar de Laura. Essa definição de papéis de gênero está atrelada a uma oposição entre modos de ser mulher e homem e de se relacionar afetivamente "no mundo" e "nos padrôes cristãos". Para Laura, por exemplo, explicando sua concepção de amor, diz que no mundo "é totalmente o contrário", pois o sexo precede o amor, enquanto no padrão cristão, o amor genuíno se diferencia do interesse sexual, embora o sexo seja visto como necessário à realização plena da conjugalidade.

Como assinala Illouz (1997), nossas experiências românticas são produzidas, significadas e expressadas por meio de padróes culturais compartilhados, ou seja, repertórios de artefatos, histórias e imagens que moldam, conceituam e normatizam as sensaçóes e relaçóes que vivenciamos. O que gostaria de chamar atenção é o fato de movimentos como o Eu Escolhi Esperar e outros grupos evangélicos, parecerem querer constituir um "estilo afetivo" próprio, com roteiros românticos característicos, algo que se exprime com força na ideia, tantas vezes repetida por inúmeros sujeitos em diferentes contextos, de uma "cultura" ou um "padrão cristão de relacionamentos" e na necessidade, constantemente reiterada, de cultivar esse padrão e transmiti-lo aos jovens. Claro que este "padrão cristão" também é marcado por símbolos de distinção ligados à cultura terapêutica, como vimos, e a bens de consumo (como luxuosas viagens de lua de mel e festas de casamento que compóem as narrativas de testemunhos). Sua característica mais específica é, porém, o conjunto de normas quanto aos papéis de gênero, a sexualidade, o formato da relação, seus estágios e limites, bem como a própria finalidade do namoro. A noção de "cultura" utilizada nos discursos dos sujeitos, serve, sobretudo, para marcar uma diferença em relação à "cultura do mundo", imaginada

${ }^{11}$ Efésios 5:22-28. Bíblia Online: <https://www.bibliaonline.com.br/vc/ef/5>. Acesso em: 20 jan. 2018. 
como hegemônica e normativa, na qual os relacionamentos afetivos estariam desvalorizados e frágeis, utilitários e "líquidos" ${ }^{2}$. Uma sociedade na qual todos buscariam prazeres fugazes, a satisfação sexual individualista, em detrimento da construção de relações saudáveis e estáveis, resultando em coraçóes partidos e pessoas emocionalmente doentes.

\section{REFERENNCIAS}

ALVES, Vera Lúcia Pereira. Receitas para a conjugalidade: uma análise da literatura de auto-ajuda. 2005. Tese (Doutorado em Educação) - Unicamp, Campinas, 2005.

AZEVEDO, Thales. As regras do namoro a antiga: aproximaçóes socioculturais. São Paulo: Ática, 1986.

BAUMAN, Zygmunt. Amor líquido: sobre a fragilidade dos laços humanos. Rio de Janeiro: Zahar, 2004.

BELELI, Iara. O imperativo das imagens: construção de afinidades nas mídias digitais. Cadernos Pagu, Campinas, n. 44, p. 91-114, 2015.

BUTLER, Judith. Problemas de gênero: feminismo e subversão da identidade. Rio de Janeiro: Civilização Brasileira, 2003.

COUTO, Marcia Teresa. Na trilha do gênero: pentecostalismo e CEBs. Revista Estudos Feministas, Florianópolis, v. 10, n. 2, p. 357-369, 2002.

ESTEBAN, Maria Luz. Crítica del pensamiento amoroso: temas contemporáneos. Barcelona: Bellaterra, 2011.

FOUCAULT, Michel. História da Sexualidade: a vontade de saber. v. 1. Rio de Janeiro: Graal, 1979.

12 É notório o fato de muitos interlocutores fazerem referência direta ao conceito de liquidez do sociólogo Zygmunt Bauman (2004), demonstrando a difusão de sua obra.

Debates do NER, Porto Alegre, ANo i9, N. 34, P. 25 I-277, Ago./Dez. 20 i 8 
GIDDENS, Anthony. A Transformação da Intimidade: sexualidade, amor e erotismo nas sociedades modernas. São Paulo: Unesp, 1993.

HEILBORN, Maria Luiza. Dois épar: gênero e identidade sexual em contexto igualitário. Rio de Janeiro: Garamond, 2004.

ILLOUZ, Eva. Consuming the romantic utipia: love and the cultural contradictions of capitalism. Berkeley: California University Press, 1997. . O amor nos tempos do capitalismo. Rio de Janeiro: Zahar, 2011.

LUTZ, Catherine A. Engendered Emotion: gender, power, and the rhetoric of emotional control in American discourse. In: HARRÉ, Rom; PARROTT, Gerrod (Org.). The emotions. Thousand Oaks: Sage, 1996. p. 152-170.

MACHADO, Maria. Carismáticos e pentecostais: adesão religiosa na esfera familiar. São Paulo: Autores Associados; ANPOCS, 1996.

POVINELLI, Elizabeth. The Empire of love: toward a theory of intimacy, genealogy and carnality. Durham, N.C.: Duke University Press, 2006.

ROSE, Nikolas. Governing the soul: the shaping of the private self. Londres: Free Association Books, 1999.

VIVEIROS DE CASTRO, Eduardo; BENZAQUIM ARAÚJO, Ricardo. Romeu e Julieta e a origem do Estado. In: VELHO, Gilberto (Org.). Arte e Sociedade: ensaios de sociologia da arte. Rio de Janeiro: Zahar, 1977. p. 130-169.

Recebido em: 01/08/2018 Aprovado em: 15/10/2018 
